\title{
ANALISIS KEMAMPUAN REPRESENTASI MATEMATIS SISWA PADA MATERI SISTEM PERSAMAAN LINEAR DUA VARIABEL (SPLDV) DI KELAS VIII 3 MTS AL-JAM'IYATUL WASLIYAH TEMBUNG
}

Oleh:

\author{
Latifah Marhamah Harahap ${ }^{1}$, Fibri Rakhmawati ${ }^{2}$ \\ ${ }^{1}$ Pendidikan Matematika, Fakultas Ilmu Tarbiyah dan Keguruan, Universitas Islam Negeri \\ Sumatera Utara \\ ${ }^{2}$ Pendidikan Matematika, Fakultas Ilmu Tarbiyah dan Keguruan, Universitas Islam Negeri \\ Sumatera Utara \\ E-mail: ${ }^{1}$ latifahmh@gmail.com, ${ }^{2}$ fibree_r@yahoo.com
}

doi : 10.3082/axiom.v9i1.7235

\begin{abstract}
Abstrak:
Penelitian ini bertujuan untuk mengetahui kemampuan representasi matematis siswa MTs AlWashliyah Tembung di kelas VIII 3 dalam menyelesaikan masalah dari materi Sistem Persamaan Linier Dua Variabel (SPLDV). Penelitian ini adalah penelitian kualitatif. Dalam penelitian ini 6 subjek diambil sebagai subjek wawancara yang mewakili 3 kelompok, yaitu kelompok atas, kelompok menengah, dan kelompok bawah ditentukan berdasarkan hasil tes. Kriteria untuk subjek wawancara adalah subjek yang dapat mewakili jawaban masing-masing kelompok dan dapat berkomunikasi dengan baik. Pengumpulan data dilakukan dengan metode pengujian, dokumentasi, dan wawancara dengan siswa. Berdasarkan hasil penelitian ditemukan bahwa ada siswa yang kurang mampu untuk membuat representasi visual sesuai dengan informasi dalam pertanyaan, tidak memiliki pemahaman dalam menjawab pertanyaan tentang kemampuan representasi ekspresi, dan masih mengalami kesulitan menulis representasi verbal dan menjelaskannya.
\end{abstract}

Kata Kunci:

Kemampuan Representasi Matematis

\section{Abstract:}

This study aims to determine the mathematical representation ability of students of MTs AlWashliyah Tembung in class VIII 3 in solving material problems of the Two Variable Linear Equation System (SPLDV). This research is a qualitative research. In this study 6 subjects were taken as interview subjects who were representatives of 3 groups, namely the upper group, middle group, and lower group determined based on test results. Criteria for interview subjects are subjects that can represent the answers of each group and can communicate well. Data collection is done by the method of testing, documentation, and interviews with students. Based on the results of the study, it was found that there were students who were less able to make visual representations in accordance with the information in the questions, lacked understanding in answering questions about the ability of expression representation. Also still having difficulty writing verbal representations and explaining them. 


\section{Keywords:}

\section{Mathematical Representation Ability}

\section{A. Pendahuluan}

Matematika merupakan salah satu bidang studi yang ada pada semua jenjang pendidikan, mulai dari tingkat sekolah dasar hingga perguruan tinggi. Bahkan matematika diajarkan di taman kanak-kanak secara informal. Penting untuk menelisik lebih jauh bagaimana kenyataan matematika sebagai bidang studi wajib diseluruh jenjang pendidikan di dalam proses pembelajarannya di sekolah maupun perguruan tinggi.

Belajar matematika merupakan suatu syarat cukup untuk melanjutkan pendidik dari satu jenjang ke jenjang berikutnya. Karena dengan belajar matematika, kita akan bernalar secara kritis, kreatif dan aktif. Diharapkan peserta didik terbiasa untuk bernalar secara kritis, kreatif, dan aktif setelah belajar matematika. Namun pada kenyatannya, matematika masih dianggap sulit dan kurang diminati kecuali oleh beberapa siswa. Bahkan pandangan itu terus ada pada siswa sekarang.

Jailani dan Lahinda (2014) manyatakan bahwa siswa dituntut agar membekali diri dengan pengetahuan dan keterampilan matematika untuk sukses dalam dunia yang selalu berkembang. Kebutuhan akan pemahaman dan penggunaan matematika dalam kehidupan setiap hari maupun di dunia kerja semakin besar dan terus bertambah. Oleh karena itu, pembelajaran matematika di sekolah diharapkan dapat memberikan semua siswa kesempatan untuk memahami bahkan melakukan matematika di kehidupan.

Dari pengamatan terhadap jawaban siswa pada saat pretest terlihat bahwa dalam kemampuan representasi siswa masih kurang, siswa menjabarkan apa yang diketahui dalam soal menggunakan kata-kata, tidak dengan variabel atau huruf yang dapat memudahkan menjawab soal. Dari masalah tersebut, perlu dianalisis tentang kemampuan representasi matematis siswa yang diharapkan mampu menyelesaikan permasalahan yang dihadapi siswa di kelas VIII 3 MTs Al-Jam'iyatul Washliyah Tembung.

\section{B. Kajian Teoritis}

\section{Representasi Matematis}

Menurut Rosengrant (dalam Kartini, 2009), representasi adalah sesuatu yang melambangkan objek atau proses. Menurut Goldin (2002) representasi merupakan adalah suatu konfigurasi yang bisa merepresentasikan sesuatu yang lain dalam beberapa cara. Menurutnya representasi merupakan kombinasi dari karakter, gambar, objek nyata, dan lainnya yang dapat menjelaskan sesuatu yang lain. Pendapat tersebut berdasarkan karakteristik bahwa matematika memiliki bahasa simbol yang kosong dari arti. Misalnya, sebuah kata bisa merepresentasikan objek kehidupan nyata, sebuah angka bisa merepresentasikan ukuran berat badan seseorang, auat angka juga bisa merepresentasikan posisi pada garis bilangan.

Kartini (2009) menyatakan bahwa representasi matematis merupakan ungkapanungkapan dari ide-ide matematika (masalah, pernyataan, definisi, dan lain-lain) yang digunakan untuk memperlihatkan (mengkomunikasikan) hasil kerjanya dengan cara tertentu sebagai hasil interpretasi dari pikirannya. Representasi merupakan suatu model atau bentuk yang digunakan untuk mewakili suatu situasi atau masalah agar dapat mempermudah pencarian solusi (Murni, 2013). Sejalan dengan itu, Bruner (1977) menyatakan bahwa keberhasilan masalah termasuk membuat dan menggunakan representasi matematis berupa kata-kata, grafik, tabel, dan persamaan, penyelesaian, dan manipulasi simbol. Dari pernyataan tersebut tampak bahwa representasi merupakan alat untuk memecahkan masalah.

Beberapa bentuk representasi yang digunakan dalam pembelajaran matematika menurut Lesh Post, dan Behr (dalam Van de Walle, 2008) diantaranya objek dunia nyata, representasi konkrit, representasi simbol aritmatika, representasi bahasa lisan atau verbal, dan representasi gambar atau grafik. Carpenter dalam Harries dan Barmby (2006) membagi represenasi menjadi dua bagian yakni representasi eksternal dan internal. Representasi eksternal, terdiri dari bahasa 
lisan, simbol tertulis, gambaran atau objek fisik. Sementara untuk berfikir tentang gagasan matematika maka mengharuskan representasi internal. Representasi internal (representasi mental) ini tidak bisa secara langsung diamati karena merupakan aktivitas mental dalam otaknya.

Miura (2001) membagi representasi menjadi dua macam, yaitu: (a) Representasi instruksional (yang bersifat pelajaran) seperti definisi, contoh, dan model, yang digunakan guru untuk menanamkan pengetahuan kepada siswa. (b) Representasi kognitif yang dibangun oleh siswa itu sendiri sambil mereka mencoba membuat konsep matematika dapat dimengerti atau mencoba untuk menemukan solusi dari suatu masalah. Friedlander dan Tabach (2001) membagi representasi menjadi empat macam, yaitu representasi verbal, representasi numerik, representasi grafik dan representasi aljabar. Sedangkan Mudzakkir (dalam Suryana, 2012) mengelompokkan representasi matematika kedalam tiga bentuk, yaitu: (1) representasi berupa diagram, grafik, atau tabel, dan gambar; (2) persamaan atau ekspresi matematika; (3) kata-kata atau teks tertulis,

\section{Kemampuan Representasi Matematis}

NCTM (2000) menetapkan lima standar proses yang harus dimiliki siswa, yaitu pemecahan masalah, penalaran, komunikasi, koneksi, dan representasi. Kelima standar proses tersebut tidak bisa dipisahkan dari pembelajaran matematika, karena kelimanya saling terkait satu sama lain dalam proses belajar dan mengajar matematika. Standar representasi menekankan pada penggunaan simbol, bagan, grafik dan tabel dalam menghubungkan dan mengekspresikan ide-ide matematika. Penggunaan hal-hal tersebut harus dipahami siswa sebagai cara untuk mengkomunikasikan ide-ide matematika kepada orang lain (Mutmainnah, 2014).

Hal tersebut menunjukkan bahwa representasi merupakan salah satu standar kemampuan yang harus ada dalam pembelajaran matematika. Standar yang ditetapkan NCTM (2000) untuk standar representasi bahwa harus memungkinkan siswa untuk: (a) membuat dan menggunakan representasi untuk mengatur, mencatat, dan mengkomunikasikan ide-ide matematika, (b) memilih, menerapkan, dan menterjemahkan antar representasi matematika untuk memecahkan masalah, (c) menggunakan representasi untuk memodelkan dan menginterpretasikan fenomena fisik, sosial, dan matematika.

Mudzakir (dalam Muthmainnah, 2014) mengelompokkan representasi matematis ke dalam tiga bentuk, yaitu representasi visual, persamaan atau ekspresi matematis dan kata-kata atau teks tertulis. Selanjutnya ketiga bentuk tersebut diuraikan ke dalam bentuk-bentuk operasional yang dapat dilihat pada Tabel 1 .

Tabel 1. Indikator Kemampuan Representasi Matematis

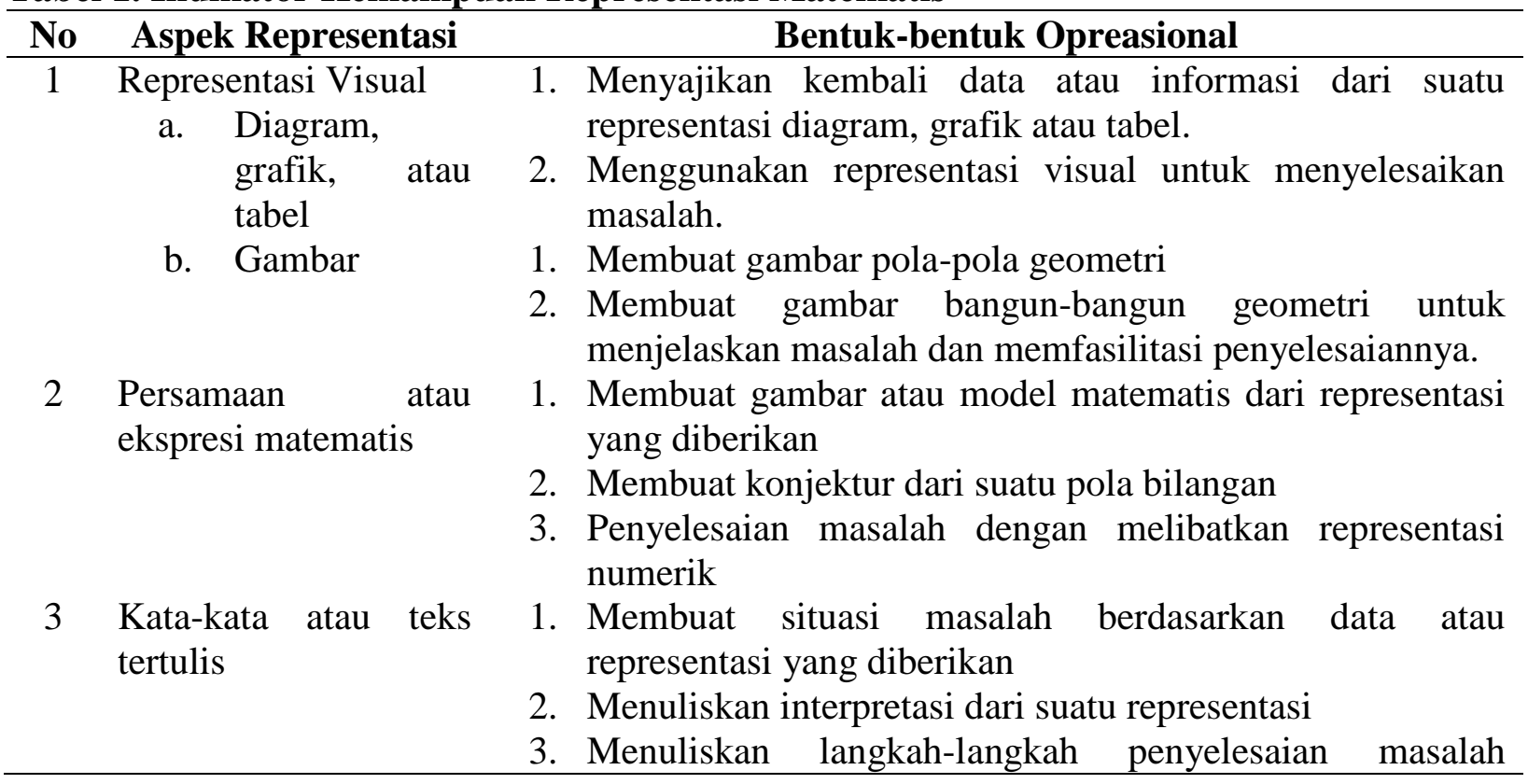


matematika dengan kata-kata

4. Menyususn cerita yang sesuai dengan suatu representasi yang disajikan

5. Menjawab soal dengan menggunakan kata-kata atau teks tertulis

\section{Metode Penelitian}

Penelitian ini adalah salah satu dari bentuk penelitian kualitatif, karena penelitian ini memiliki tujuan untuk menganalisis representatis matematis siswa melalui gambaran yang menyeluruh dan memperbanyak pemahaman yang mendalam mengenai penelitian yang akan diteliti, kesimpulan yang diambil dari penelitian ini juga bersifat induktif atau kesimpulan dapat diambil apabila pengamatan sudah selesai dilaksanakan dan latar penelitian bersifat natural (apa adanya).

Subjek dalam penelitian ini yaitu siswa kelas VIII 3 MTs Al-Jam'iyatul Washliyah Tembung berjumlah 34 orang. Kemudian subyek yang akan dipilih dan diketahui terlebih dahulu kemampuannya. Pemilihan subjek dilakukan dengan cara memberikan tes kemampuan hasil belajar matematika sebagai upaya untuk menentukan tingkat kemampuan matematika siswa. Kemudian siswa akan dipilih kembali untuk ditentukan sebagai informan atau subjek penelitian sesuai dengan kemampuannya masing-masing yang terdiri dari 2 siswa tingkat kemampuan atas, 2 siswa tingkat kemampuan sedang, dan 2 siswa tingkat kemampuan rendah. Dengan jumlah keseluruhan subjek yang dipilih 6 siswa.

Penelitian ini menggunakan 3 prosedur pengumpulan data yaitu wawancara, observasi dan dokumentasi. Sedangkan Teknik analisis data yang digunakan terdiri dari reduksi data, penyajian data dan menarik kesimpulan/verifikasi.

D. Hasil Penelitian dan Pembahasan

1. Kemampuan Representasi Matematis Siswa Kelompok Bawah

a. Kemampuan representasi visual matematis

Tabel 2. Kemampuan Representasi Visual Matematis Subyek Kelompok Bawah

\begin{tabular}{cccccc}
\hline $\begin{array}{c}\text { Kemampuan } \\
\text { Representasi }\end{array}$ & $\begin{array}{c}\text { Subyek } \\
\text { Penelitian }\end{array}$ & $\begin{array}{c}\text { Nomor } \\
\text { Soal }\end{array}$ & Skor & $\begin{array}{c}\text { Persentase } \\
\text { Skor }\end{array}$ & Kategori \\
\hline \multirow{2}{*}{$\begin{array}{c}\text { Representasi } \\
\text { Visual }\end{array}$} & $\mathrm{S}_{1}$ & 3 & 0 & $0 \%$ & Sangat Rendah \\
& & 6 & 0 & $0 \%$ & Sangat Rendah \\
& $\mathrm{S}_{2}$ & 3 & 0 & $0 \%$ & Sangat Rendah \\
& & 6 & 0 & $0 \%$ & Sangat Rendah \\
\hline
\end{tabular}

b. Kemampuan representasi ekspresi matematis

Tabel 3. Kemampuan Representasi Ekspresi Matematis Subyek Kelompok Bawah

\begin{tabular}{cccccc}
\hline $\begin{array}{c}\text { Kemampuan } \\
\text { Representasi }\end{array}$ & $\begin{array}{c}\text { Subyek } \\
\text { Penelitian }\end{array}$ & No & Skor & $\begin{array}{c}\text { Persentase } \\
\text { Skor }\end{array}$ & Kategori \\
\hline Representasi & $\mathrm{S}_{1}$ & 1 & 0 & $0 \%$ & Sangat Rendah \\
Ekspresi & & 4 & 0 & $0 \%$ & Sangat Rendah \\
& $\mathrm{S}_{2}$ & 1 & 2 & $50 \%$ & Sedang \\
& & 4 & 1 & $25 \%$ & Rendah \\
\hline
\end{tabular}

c. Kemampuan representasi verbal matematis

Tabel 4. Kemampuan Representasi Verbal Matematis Subyek Kelompok Bawah

\begin{tabular}{cccccc}
\hline $\begin{array}{l}\text { Kemampuan } \\
\text { Representasi }\end{array}$ & $\begin{array}{c}\text { Subyek } \\
\text { Penelitian }\end{array}$ & No & Skor & $\begin{array}{c}\text { Persentase } \\
\text { Skor }\end{array}$ & Kategori \\
\hline \multirow{2}{*}{ Representasi } & $\mathrm{S}_{1}$ & 2 & 2 & $50 \%$ & Sedang \\
Verbal & & 5 & 0 & $0 \%$ & Sangat Rendah \\
& $\mathrm{S}_{2}$ & 2 & 0 & $0 \%$ & Sangat Rendah \\
& & 5 & 0 & $0 \%$ & Sangat Rendah \\
\hline
\end{tabular}


2. Kemampuan Representasi Matematis Siswa Kelompok Tengah

a. Kemampuan representasi visual matematis

Tabel 5. Kemampuan Representasi Visual Matematis Subyek Kelompok Tengah

\begin{tabular}{cccccc}
\hline $\begin{array}{c}\text { Kemampuan } \\
\text { Representasi }\end{array}$ & $\begin{array}{c}\text { Subyek } \\
\text { Penelitian }\end{array}$ & $\begin{array}{c}\text { Nomor } \\
\text { Soal }\end{array}$ & Skor & $\begin{array}{c}\text { Persentase } \\
\text { Skor }\end{array}$ & Kategori \\
\hline & \multirow{2}{*}{$\mathrm{S}_{3}$} & 3 & 4 & $100 \%$ & Sangat Tinggi \\
Representasi & & 6 & 0 & $0 \%$ & Sangat Rendah \\
Visual & $\mathrm{S}_{4}$ & 3 & 1 & $25 \%$ & Rendah \\
& & 6 & 2 & $50 \%$ & Sedang \\
\hline
\end{tabular}

b. Kemampuan representasi ekspresi matematis

Tabel 6. Kemampuan Representasi Ekspresi Matematis Subyek Kelompok Tengah

\begin{tabular}{cccccc}
\hline $\begin{array}{c}\text { Kemampuan } \\
\text { Representasi }\end{array}$ & $\begin{array}{c}\text { Subyek } \\
\text { Penelitian }\end{array}$ & No & Skor & $\begin{array}{c}\text { Persentase } \\
\text { Skor }\end{array}$ & Kategori \\
\hline Representasi & $\mathrm{S}_{3}$ & 1 & 2 & $50 \%$ & Sedang \\
Ekspresi & & 4 & 0 & $0 \%$ & Sangat Rendah \\
& $\mathrm{S}_{4}$ & 1 & 1 & $25 \%$ & Rendah \\
& & 4 & 1 & $25 \%$ & Rendah \\
\hline
\end{tabular}

c. Kemampuan representasi verbal matematis

Tabel 7. Kemampuan Representasi Verbal Matematis Subyek Kelompok Tengah

\begin{tabular}{cccccc}
\hline $\begin{array}{c}\text { Kemampuan } \\
\text { Representasi }\end{array}$ & $\begin{array}{c}\text { Subyek } \\
\text { Penelitian }\end{array}$ & No & Skor & $\begin{array}{c}\text { Persentase } \\
\text { Skor }\end{array}$ & Kategori \\
\hline & $\mathrm{S}_{3}$ & 2 & 3 & $75 \%$ & Tinggi \\
Representasi & & 5 & 0 & $0 \%$ & Sangat Rendah \\
Verbal & $\mathrm{S}_{4}$ & 2 & 3 & $75 \%$ & Tinggi \\
& & 5 & 2 & $50 \%$ & Sedang \\
\hline
\end{tabular}

3. Kemampuan Representasi Matematis Siswa Kelompok Atas

a. Kemampuan representasi visual matematis

Tabel 8. Kemampuan Representasi Visual Matematis Subyek Kelompok Atas

\begin{tabular}{cccccc}
\hline $\begin{array}{l}\text { Kemampuan } \\
\text { Representasi }\end{array}$ & $\begin{array}{c}\text { Subyek } \\
\text { Penelitian }\end{array}$ & $\begin{array}{c}\text { Nomor } \\
\text { Soal }\end{array}$ & Skor & $\begin{array}{c}\text { Persentase } \\
\text { Skor }\end{array}$ & Kategori \\
\hline \multirow{2}{*}{ Representasi } & $\mathrm{S}_{5}$ & 3 & 4 & $100 \%$ & Sangat Tinggi \\
Visual & & 6 & 3 & $75 \%$ & Tinggi \\
& $\mathrm{S}_{6}$ & 3 & 4 & $100 \%$ & Sangat Tinggi \\
& & 6 & 0 & $0 \%$ & Sangat Rendah \\
\hline
\end{tabular}

b. Kemampuan representasi ekspresi matematis

Tabel 9. Kemampuan Representasi Ekspresi Matematis Subyek Kelompok Atas

\begin{tabular}{cccccc}
\hline $\begin{array}{c}\text { Kemampuan } \\
\text { Representasi }\end{array}$ & $\begin{array}{c}\text { Subyek } \\
\text { Penelitian }\end{array}$ & No & Skor & $\begin{array}{c}\text { Persentase } \\
\text { Skor }\end{array}$ & Kategori \\
\hline Representasi & $\mathrm{S}_{5}$ & 1 & 2 & $50 \%$ & Sedang \\
Ekspresi & & 4 & 1 & $25 \%$ & Rendah \\
& $\mathrm{S}_{6}$ & 1 & 4 & $100 \%$ & Sangat Tinggi \\
& & 4 & 1 & $25 \%$ & Rendah \\
\hline
\end{tabular}


c. Kemampuan representasi verbal matematis kelompok atas

Tabel 10. Kemampuan Representasi Verbal MAtematis Subyek Kelompok Atas

\begin{tabular}{cccccc}
\hline $\begin{array}{c}\text { Kemampuan } \\
\text { Representasi }\end{array}$ & $\begin{array}{c}\text { Subyek } \\
\text { Penelitian }\end{array}$ & No & Skor & $\begin{array}{c}\text { Persentase } \\
\text { Skor }\end{array}$ & Kategori \\
\hline \multirow{2}{*}{ Representasi } & $\mathrm{S}_{5}$ & 2 & 2 & $50 \%$ & Sedang \\
Verbal & & 5 & 3 & $75 \%$ & Tinggi \\
& $\mathrm{S}_{6}$ & 2 & 4 & $100 \%$ & Sangat Tinggi \\
& & 5 & 4 & $100 \%$ & Sangat Tinggi \\
\hline
\end{tabular}

Berdasarkan hasil analisis data mengenai kemampuan representasi matematis siswa dalam materi sistem persamaan linear dua variabel diperoleh perbedaan kemampuan dari setiap kelompok siswa. Pembahasan akan dipaparkan sesuai indikator kemampuan representasi matematis siswa.

1) Kemampuan representasi visual matematis

Berdasarkan hasil penelitian, diperoleh informasi bahwa siswa dari kelompok bawah dengan kode $\mathrm{S}_{1}$ tidak mampu menjawab soal. Subyek tidak dapat menyelesaikan soal kemampuan representasi visual matematis sehingga $S_{1}$ tidak mengerjakannya sama sekali. Untuk soal 3 dan 6 , subyek tidak menjawabnya sama sekali sehingga skornya tidak ada. Subyek $S_{1}$ mengerti maksud soal yang diberikan, tetapi tidak mampu menjawabnya. Persentase rata-rata skor yang diperoleh $S_{1}$ adalah $0 \%$ dengan total skor 0 dari 8 skor, sehingga kemampuan representasi visual matematis $S_{1}$ pada kategori sangat rendah.

Siswa dari kelompok bawah dengan kode subyek $S_{2}$ juga tidak dapat mengerjakan soal 3 dan 6. Subyek masih mengalami kesulitan dalam menyelesaikan soal kemampuan representasi visual matematis. Berdasarkan analisis tes tulis dan wawancara, subyek mendapatkan skor 0 pada soal 3 dan 6 . Kemampuan representasi visual matematis subyek $S_{2}$ memiliki persentase rata-rata skor $0 \%$ dalam kategori sangat rendah dengan skor 0 dari 8 .

Siswa dari kelompok tengah dengan kode subyekS $S_{3}$ dapat memvisualisasikan soal dengan benar dan tepat pada soal 3 dan mendapat skor 4 dari 4 . Namun untuk soal 6, $S_{3}$ mendapatkan nilai yang terbalik yaitu nilai 0 dari 4 . Subyek $S_{3}$ memperoleh skor 4 dari 8 dan persentase ratarata skor yaitu sebesar $50 \%$, sehingga kemampuan representasi visual subyek $\mathrm{S}_{3}$ pada kategori sedang.

Siswa dari kelompok tengah dengan kode subyek $\mathrm{S}_{4}$, dalam soal 3 mendapatkan nilai 1 dari 4. Sedangkan pada soal 6 mendapatkan nilai 2 dari 4. Dan saat diwawancara $\mathrm{S}_{4}$ mengakui kurang memahami soal 3 dan 6 . Subyek $\mathrm{S}_{4}$ masuk dalam kategori tengah dengan skor 3 dari 8 soal dan persentase rata-rata yang diperoleh $37,50 \%$ dalam kemampuan representai visual matematis yaitu antara nilai sedang.

Siswa dengan kode subyek $S_{5}$ dari kelompok atas menjawab soal dengan nilai hampir sempurna. Soal 3 mendapat nilai 4 dari 4 dan soal 6 mendapat nilai 3 dari 4 . Subyek $\mathrm{S}_{5}$ hanya sedikit kesulitan dalam menyelesaikan soal visual kemampuan representasi matematis, dikarenakan subyek $\mathrm{S}_{5}$ paham dan mengerti dengan apa yang diketahui dan ditanya dalam soal, sehingga subyek $\mathrm{S}_{5}$ mendapat skor yaitu 7 dari 8 . Maka dari itu subyek $\mathrm{S}_{5}$ memliki kemampuan representasi visual matematis dengan skor $87,50 \%$ dengan kategori sangat tinggi.

Siswa dari kelompok tinggi yang lain yaitu subyek $\mathrm{S}_{6}$, hasilnya lebih rendah dari $\mathrm{S}_{6}$. Subyek $S_{6}$ kalah di soal kemampuan representasi visual matematis pada soal nomor 6 karena tidak menjawab sama sekali. $S_{6}$ dapat menjawab soal 3 dengan sempurna, yaitu skor 4 dari 4 . Tetapi di soal $6, \mathrm{~S}_{6}$ mendapat skor 0 dari 4 karena tidak sempat untuk menjawabnya. Maka dari itu, subyek $\mathrm{S}_{6}$ mendapat skor 4 dari 8 dengan persentase rata-rata skor yaitu $50 \%$, sehingga subyek $\mathrm{S}_{6}$ mendapat kategori sedang dalam soal kemampuan representasi visual matematis.

2) Kemampuan representasi ekspresi matematis

Siswa dari kelompok bawah dengan kode subyek $S_{1}$ tidak satupun soal kemampuan representasi ekspresi yang dapat dijawabnya. Semua soal 1 dan 4 mendapat nilai tidak bagus yakni 0 dari 4 . Subyek $S_{1}$ sangat mengalami kesulitan dalam menyelesaikan soal tersebut. Dalam hasil wawancara, $S_{1}$ tidak mengerjakan soal karena tidak mengerti cara mengerjakannya. Maka 
dari itu subyek $\mathrm{S}_{1}$ mendapat skor 0 dari 8 , dan rata-rata skor $0 \%$, sehingga mendapat kategori sangat rendah.

Siswa dari kelompok bawah selanjutnya yaitu subyek $S_{2}$ mendapat nilai yang berbeda dengan $\mathrm{S}_{2}$. Dari soal 1 mendapat skor 2 dari 4 dan soal 4 mendapat skor 1 dari 4 . Hal ini dikarenakan subyek $S_{2}$ kurang memahami soal dengan baik. Dari hasil wawancara juga subyek $\mathrm{S}_{2}$ mengatakan kurang paham dalam mengerjakannya. Maka dari itu, subyek $\mathrm{S}_{2}$ mendapat skor 3 dari 8 dan persentase rata-rata skor subyek $S_{2}$ adalah $37,50 \%$, sehingga subyek $S_{2}$ dalam kategori sedang kemampuan representasi ekspresi matematisnya.

Selanjutnya pada kelompok tengah, yaitu subyek $S_{3}$ juga mengalami kesulitan. $S_{3}$ hanya bisa mengerjakan soal 1 dan mendapat skor 2 dari 4. Sedangkan soal 4 mendapat skor 0 dari 4. Subyek $\mathrm{S}_{3}$ ketika menjawab soal kemampuan representasi ekspresi matematis mengalami kesulitan membuat model matematika yang kedua. Maka subyek $\mathrm{S}_{3}$ hanya mendapatkan skor 2 dari 8. Persentase rata-rata skor yaitu $25 \%$, sehingga subyek $\mathrm{S}_{3}$ dalam kategori rendah dalam kemampuan representasi ekspresi matematis.

Kemudian $\mathrm{S}_{4}$ dari kelompok tengah hanya mengerjakan soal 1 dan 4 , tetapi jawabannya masih sangat kurang. Dalam soal 1 subyek $\mathrm{S}_{4}$ mendapat skor 1 dari 4 dan soal 4 juga mendapat skor 1 dari 4. Subyek $\mathrm{S}_{4}$ sangat mengalami kesulitan dalam menjawab soal kemampuan representasi ekspresi matematis sesuai dengan hasil wawancara. Hal ini subyek $\mathrm{S}_{4}$ hanya mendapatkan skor 2 dari 8 dan rata-rata skor $25 \%$, yang membuat subyek $\mathrm{S}_{4}$ masuk kategori rendah dalam kemampuan representasi ekspresi matematis.

Siswa dari kelompok atas dengan kode subyek $S_{5}$ menjawab semua soal. Tetapi jawabannya kurang memuaskan. Dari soal 1 subyek $S_{5}$ mendapat skor 2 dari 4 dan soal 4 mendapat skor 1 dari $4 . S_{5}$ mengakui dalam menjawab soal masih mengalami kesulitan dikarenakan kurang mengerti dengan apa yang ditanyakan didalam soal. Model matematika pertama yang dibuat selalu benar, tetapi model matematika kedua salah. Subyek memperoleh skor total yaitu 3 dari 8, dan persentase rata-rata skor subyek $\mathrm{S}_{5}$ adalah 37,50\%. Sehingga subyek $\mathrm{S}_{5}$ dalam kategori sedang dalam kemampuan representasi ekspresi matematis.

Dan yang terakhir dari kelompok atas dengan kode subyek $S_{6}$, soal 1 mendapat skor 4 dari 4 dan soal 4 mendapat skor 1 dari 4 . Subyek $S_{6}$ mengalami kesulitan ketika menyelesaikan soal 4. Soal $1 \mathrm{~S}_{6}$ menjawabnya dengan tepat, tetapi soal 4 tidak dikarenakan kurang memahami soal yang diberikan. Jadi subyek $\mathrm{S}_{6}$ memperoleh skor 5 dari 8 , dan persentasi rata-rata skor yaitu $62,50 \%$, sehingga kemampuan representasi ekspresei matematis dalam kategori tinggi.

3) Kemampuan representasi verbal matematis

Siswa dari kelompok bawah dengan kode subyek $S_{1}$ menuliskan 1 jawaban dari 2 soal. Dalam soal 2, $\mathrm{S}_{1}$ kurang memahami apa yang diminta dalam soal. Dari hasil yang didapatkan, $\mathrm{S}_{1}$ sedikit menjelaskan menggunakan kalimat dan lebih banyak menjelaskan dalam bentuk model matematika. Alasannya karena lebih mudah membuatnya. Dari soal 2, $S_{1}$ mendapat skor 2 dari 4 dan soal 5 mendapat skor 0 dari 4. Dengan begitu kemampuan representasi verbal matematis subyek $S_{1}$ mendapatkan persentase rata-rata skor sebesar $25 \%$ dan termasuk dalam kategori rendah.

Siswa dari kelompok bawah dengan kode subyek $\mathrm{S}_{2}$ tidak dapat menuliskan sama sekali jawaban dari semua soal kemampuan representasi verbal matematis. Soal 2 dan soal 5 masingmasing mendapat skor 0 dari 4 . Sehingga subyek $S_{2}$ mendapatkan nilai tidak memuaskan yaitu 0 dari 8. Hasil wawancara menunjukkan bahwa subyek $S_{2}$ mengalami kesulitan seperti bingung dengan soalnya, tidak paham dan juga tidak mengerti cara menjawab soal tersebut. Maka dari itu subyek $\mathrm{S}_{2}$ mendapatkan skor 0 dari 8 dan persentase rata-rata skor yaitu $0 \%$, sehingga membuat subyek $S_{2}$ masuk dalam kategori sangat rendah kemampuan representasi verbal matematis.

Siswa dari kelompok tengah dengan kode subyek $\mathrm{S}_{3}$ menjawab soal kemampuan representasi verbal matematis kurang memuaskan. Dari 2 soal, $S_{3}$ dapat menjawab salah satu walaupun masih kurang tepat. Soal 2 mendapat skor 3 dari 4 dan soal 5 mendapat skor 0 dari 4 . Dari hasil wawancara subyek $\mathrm{S}_{3}$ masih kurang dalam menjelaskan apa yang dimaksudkan dalam soal. Dan juga karena pengerjaannya yang lambat sehingga soal yang lain tidak dapat dikerjakan. 
Maka dari itu subyek $S_{3}$ hanya mendapatkan skor 3 dari 8 dan persentase rata-rata skor yaitu $37,50 \%$. Sehingga kemampuan representasi verbal matematis subyek $\mathrm{S}_{3}$ termasuk dalam kategori sedang.

Selanjutnya siswa dari kelompok tengah dengan kode subyek $\mathrm{S}_{4}$ dapat menjawab kedua soal walaupun masih kurang tepat. Subyek $S_{4}$ juga mengalami kesulitan ketika menjawab soal tersebut, dikarenakan masih kurangnya pemahaman subyek, sesuai dengan hasil wawancara dengan subyek $\mathrm{S}_{4}$. Dari soal 2 mendapat skor 3 dari 4 dan soal 5 mendapat skor 2 dari 4 . Bila dijumlahkan subyek $\mathrm{S}_{4}$ memperoleh skor 5 dari 8, dan persentase rata-rata skor yaitu $62,50 \%$. Sehingga kemampuan subyek $\mathrm{S}_{4}$ dalam kategori kemampuan representasi verbal matematis tinggi.

Siswa dari kelompok atas dengan kode subyek $\mathrm{S}_{5}$ dapat menjawab semua soal walaupun tidak sesuai dengan yang diharapkan. Walaupun subyek $\mathrm{S}_{5}$ kesulitan dalam menjawab, subyek $\mathrm{S}_{5}$ masih mengerjakan soal dengan semampunya. Dari soal 2 mendapat skor 2 dari 4 dan soal 5 mendapat skor 3 dari 4 . Maka dari itu subyek $S_{5}$ mendapat skor 5 dari 8 dan persentase 62,50\%. Sehingga subyek $S_{5}$ termasuk dalam kategori tinggi kemampuan representasi verbal matematisnya.

Siswa dari kelompok atas lainnya dengan kode subyek $\mathrm{S}_{6}$ dapat menjawab semua soal dengan nilai yang sangat memuaskan. Dari soal 2 subyek $S_{6}$ mendapat skor 4 dari 4 dan soal 5 mendapat skor 4 dari 4 . Ini dapat dibuktikan saat diwawancara $\mathrm{S}_{6}$ memahami apa yang ditanyakan dalam soal. Maka dari itu subyek $\mathrm{S}_{6}$ memperoleh skor 8 dari 12 dan persentase ratarata skor $100 \%$, sehingga subyek $S_{6}$ termasuk dalam kategori sangat tinggi dalam kemampuan representasi verbal matematis.

Tabel 11. Kemampuan Representasi Matematis Siswa

\begin{tabular}{cccccc}
\hline $\begin{array}{c}\text { Kemampuan } \\
\text { Representasi }\end{array}$ & Kelompok & $\begin{array}{c}\text { Subyek } \\
\text { Penelitian }\end{array}$ & Skor & $\begin{array}{c}\text { Persentase } \\
\text { Rata-rata } \\
\text { Skor }\end{array}$ & Kategori \\
\hline Representasi & Bawah & $\mathrm{S}_{1}$ & 0 dari 8 & $0 \%$ & Sangat Rendah \\
Visual & Tengah & $\mathrm{S}_{2}$ & 0 dari 8 & $0 \%$ & Sangat Rendah \\
& & $\mathrm{S}_{3}$ & 4 dari 8 & $50 \%$ & Sedang \\
& Atas & $\mathrm{S}_{4}$ & 3 dari 8 & $37,50 \%$ & Sedang \\
& & $\mathrm{S}_{5}$ & 7 dari 8 & $87,50 \%$ & Sangat Tinggi \\
& Bawah & $\mathrm{S}_{6}$ & 4 dari 8 & $50 \%$ & Sedang \\
Representasi & $\mathrm{S}_{1}$ & 0 dari 8 & $0 \%$ & Sangat Rendah \\
Ekspresi & Tengah & $\mathrm{S}_{2}$ & 3 dari 8 & $37,50 \%$ & Sedang \\
& & $\mathrm{S}_{3}$ & 2 dari 8 & $25 \%$ & Rendah \\
& Atas & $\mathrm{S}_{4}$ & 2 dari 28 & $25 \%$ & Rendah \\
& & $\mathrm{S}_{5}$ & 3 dari 8 & $37,50 \%$ & Sedang \\
Representasi & $\mathrm{S}_{6}$ & 5 dari 8 & $62,50 \%$ & Tinggi \\
Verbal & Bawah & $\mathrm{S}_{1}$ & 2 dari 8 & $25 \%$ & Rendah \\
& \multirow{2}{*}{ Tengah } & $\mathrm{S}_{2}$ & 0 dari 8 & $0 \%$ & Sangat Rendah \\
& & $\mathrm{S}_{3}$ & 3 dari 8 & $37,50 \%$ & Sedang \\
& \multirow{2}{*}{ Atas } & $\mathrm{S}_{4}$ & 5 dari 8 & $62,50 \%$ & Tinggi \\
& & $\mathrm{S}_{5}$ & 5 dari 8 & $62,50 \%$ & Tinggi \\
& & $\mathrm{S}_{6}$ & 6 dari 8 & $100 \%$ & Sangat Tinggi \\
\hline
\end{tabular}

Kemampuan representasi matematis siswa dapat dilihat pada Tabel 11. Dari analisis data diatas, kemampuan representasi visual matematis kelompok bawah untuk subyek $\mathrm{S}_{1}$ dalam kategori sangat rendah, dan subyek $S_{2}$ dalam kategori sangat rendah. Subyek $S_{3}$ dari kelompok tengah, kemampuan representasi visual matematis dalam kategori sedang. Subyek $\mathrm{S}_{4}$ dari kelompok tengah, kemampuan representasi visual matematis dalam kategori sedang. Kemampuan representasi visual matematis kelompok atas dengan subyek $\mathrm{S}_{5}$ dalam kategori sangat tinggi. Kemampuan representasi visual matematis kelompok atas dengan subyek $\mathrm{S}_{6}$ dalam kategori sedang. 
Kemampuan representasi ekspresi matematis kelompok bawah untuk subyek $\mathrm{S}_{1}$ dalam kategori sangat rendah, dan subyek $S_{2}$ dalam kategori sedang. Subyek $S_{3}$ dari kelompok tengah, kemampuan representasi ekspresi matematis dalam kategori rendah. Subyek $\mathrm{S}_{4}$ dari kelompok tengah, kemampuan representasi ekspresi matematis dalam kategori rendah. Kemampuan representasi ekspresi matematis kelompok atas dengan subyek $\mathrm{S}_{5}$ dalam kategori sedang dan subyek $\mathrm{S}_{6}$ kemampuan representasi ekspresi matematis dalam kategori tinggi.

Kemampuan representasi verbal matematis kelompok bawah untuk subyek $S_{1}$ dalam kategori rendah, dan subyek $S_{2}$ dalam kategori sangat rendah. Subyek $S_{3}$ dari kelompok tengah, kemampuan representasi verbal matematis dalam kategori sedang. Subyek $\mathrm{S}_{4}$ dari kelompok tengah, kemampuan representasi verbal matematis dalam kategori tinggi. Kemampuan representasi verbal matematis kelompok atas dengan subyek $\mathrm{S}_{5}$ dalam kategori tinggi. Kemampuan representasi visual matematis kelompok atas dengan subyek $\mathrm{S}_{6}$ dalam kategori sangat tinggi.

Kemampuan $\mathrm{S}_{1}$ dari kelompok bawah, memiliki kemampuan representasi visual dan ekspresi yang sangat rendah, sedangkan kemampuan representasi verbalnya rendah. Subyek $\mathbf{S}_{2}$ dari kelompok bawah, memiliki kemampuan representasi visual dan verbal yang sangat rendah, sedangkan kemampuan representasi ekspresinya sedang. Dari kelompok tengah dengan subyek $\mathrm{S}_{3}$ kemampuan representasi visual sedang, kemampuan representasi ekspresi rendah dan kemmapuan representasi verbal sedang. Dari kelompok tengah juga dengan subyek $\mathrm{S}_{4}$ lebih tinggi kemampuan representasi verbal matematisnya daripada kemampuan representasi ekspresi dan visual matematisnya. Dalam kelompok atas, subyek $S_{5}$ memiliki kemampuan representasi visual dan verbal yang sangat tinggi dan kemampuan representasi ekspresi yang sedang. Subyek $\mathrm{S}_{6}$ memiliki kemampuan representasi visual yang sedang, kemampuan representasi ekspresi yang tinggi dan kemampuan representasi verbal yang sangat tinggi.

\section{E. Simpulan}

Kemampuan representasi matematis dari keenam subyek penelitian yang paling tinggi yaitu kemampuan representasi verbal matematis. Sedangkan yang paling rendah yaitu kemampuan representasi ekspresi matematis.

\section{DAFTAR PUSTAKA}

Bruner, J. S. (1977). The process of education. USA: Harvard University Press.

Friedlander, A., \& Tabach, M. (2001). Promoting mutiple representasions in algebra, dalam Albert A. Cuoco dan Frances R. Curio, The Rolse of Representation in School Mathematics, Year Book.

Goldin, Gerald. (2002). Reprentation in mathematical learning and problem solving, dalam Lyn D. English, Handbook Of Internasional Reaserach In Mathematics Education, London: Lawrence Erlbaum Associates.

Harries, T., \& Barmby, P. (2006). Representing multiplication. Proceeding of the British Society for Research into Learning Mathematics. 26(3), 25-30.

https://tafsirq.com/5-Al-Ma'idah/ayat-92\#tafsir-quraish-shihab.

Jailani \& Lahinda, Y. (2014). Analisis proses pemecahan masalah matematika siswa sekolah menengah pertama. Jurnal Riset Pendidikan Matematika, 2(1), 148-161.

Kartini. (2009). Peranan representasi dalam pembelajaran matematika, disampaikan Seminar Nasional Matematika dan Pendidikan Matematika. FMIPA UNY, Yogyakarta.

Miura, Irene T. (2001). The influence of language on mathematical representations, dalam A. Cuoco, Albert dan Frances R. Curio. The Rolse of Representation in School Mathematics, Year Book.

Murni, Atma. (2013). Peningkatan kemampuan representasi matematis siswa SMP melalui pembelajaran metakognitif dan pembelajaran metakognitif berbasis soft skill. Jurnal Pendidikan, 4(2), 96-107. 
Muthmainnah. (2014). Meningkatkan kemampuan representasi matematis siswa melalui pendekatan methaporical thinking. Jakarta: UIN Syarif Hidayatullah.

NCTM. (2000). Principles and standarts for school mathematics. Reston, VA: NCTM.

Suryana, Andri. (2012). Kemampuan berpikir matematis tingkat lanjur (advanced mathematical thinking) dalam mata kuliah statistika matematika 1, Makalah Disajikan dalam Seminar Nasional Matematika dan Pendidikan Matematika, Jurusan Pendidikan Matematika FPMIPA UNY, 10 November 2012.

Van de Walle, John. (2008). Matematika: Pengembangan pengajaran jilid I. Jakarta: Erlangga. 